\title{
On Leucocytozoon parasites of Ardeidae and description of one species
}

\author{
by C. PRIgIONI, E. BRAMBILLA, F. BARBIERI and M. FASOLA
}

Istituto di Zoologia, Università di Pavia, Piazza Botta, 9, 27100 Pavia, Italy

SUMMARY. In peripheral blood of Nycticorax nycticorax and Egretta garzetta (Aves, Ardeidae), gametocytes of the genus Leucocytozoon (Protozoa, Sporozoa) were found. We describe this parasite and compare it with the past records of Leucocytozoon in Ardeidae. While only life cycle studies will give a definitive answer to these taxonomic problems, we put forward an hypothesis about taxonomy of Leucocytozoon in Ardeidae.

\section{Leucocytozoon des Ardeidae et description d'une espèce.}

RESUME. Dans le sang périphérique de Nycticorax nycticorax et de Egretta garzetta (Aves, Ardeidae) ont été trouvés des gamétocytes du genre Leucocytozoon (Protozoa, Sporozoa). Nous décrivons ce parasite et, bien que seule l'étude de leur cycle biologique permette de résoudre les problèmes taxonomiques, nous proposons une révision de la classification des Leucocytozoon signalés chez les Ardeidae.

\section{Introduction}

In the order Ciconiformes, except for one record in the family Balaenicipitidae (Rodhain et al. 1913), only members of the family Ardeidae are recorded as hosts for species of Leucocytozoon. Four species have been described, but two (L. ardeolae and $L$. iowense) are believed by Fallis et al. (1974) to be junior synonyms of $L$. ardeae, so that only this latter species and $L$. leboeufi may be valid. All the records known to us of Leucocytozoon sp. in Ardeidae are summarized in Table I.

Research supported by C.N.R. (C.T. 78.00374.06).

Accepté le 3 décembre 1979 


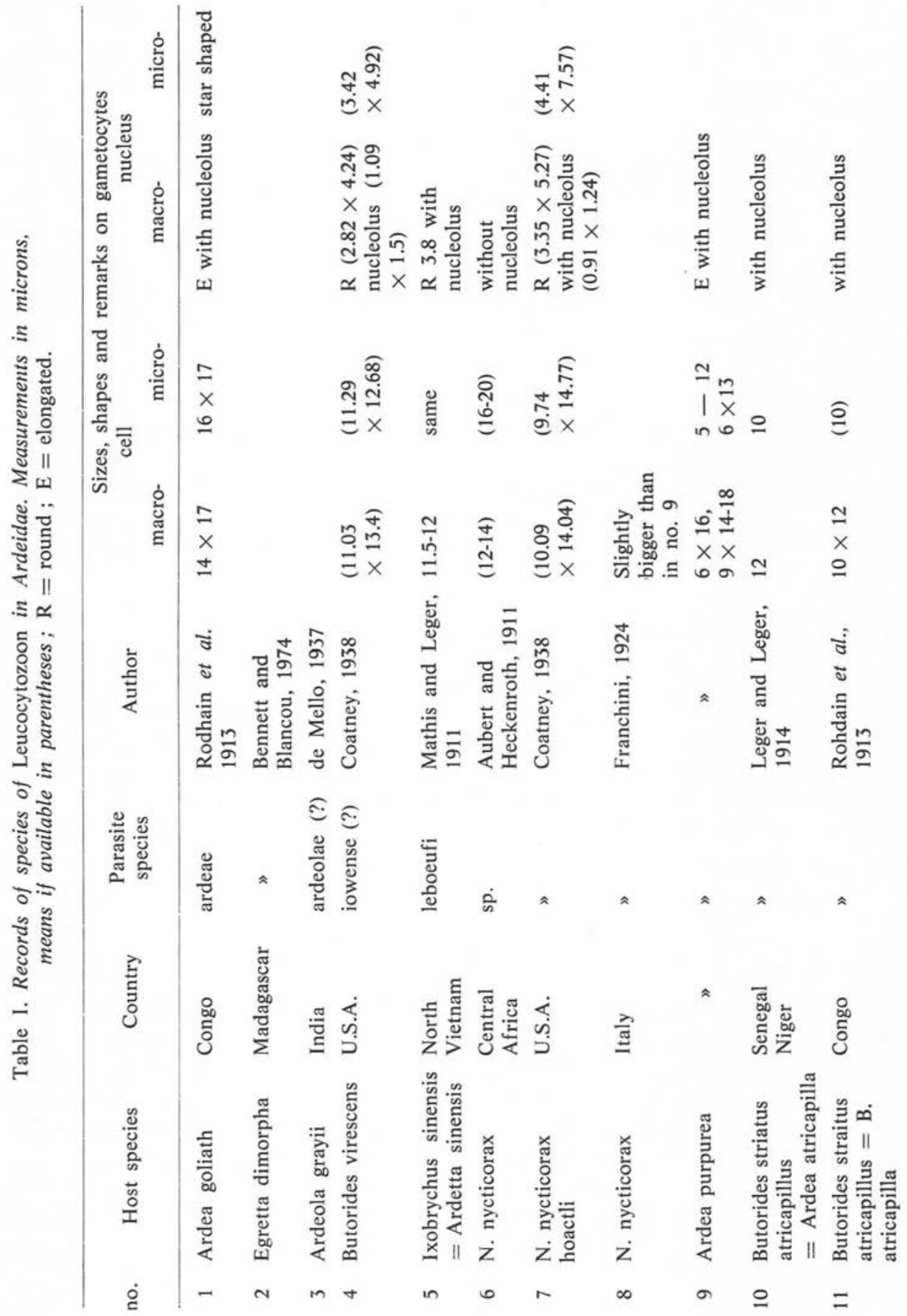


Blood smears collected during a study of nesting habits of herons in Northern Italy contained parasites of the genus Leucocytozoon.

In the present paper, we describe this material and attempt to review Leucocytozoon parasites of Ardeidae.

\section{Methods}

Blood smears were obtained during May and June 1974 to 1978 , from chicks in the nests of colonies of herons. Smears were air dried, fixed in $100 \%$ methanol, and stained in Giemsa. Blood smears were photographed using Orthoplan with Orthomat and parasites were studied using a Visopan Reichert $(1 \mathrm{~mm} .=0.8 \mu)$. Only mature gametocytes with regular shape were studied. Area measurements were made by drawing the cells on the Visopan and counting squares in a superimposed millimeter grid. Indices defined by Bennett et al. (1974) were calculated. Gametocytaemia was expressed as number of parasites per 1000 erythrocytes. Names of birds are from Peters (1931).

\section{Results}

From 1974 to 1978 blood smears were taken form 102 birds (72 night herons Nycticorax nycticorax, 11 little egrets Egretta garzetta and 19 purple herons Ardea purpurea) in nine heronries spaced 10 or $20 \mathrm{~km}$ apart near Pavia, Northern Italy. Of these birds, 12 were infected by Leucocytozoon : 8 of 11 night herons examined and 3 of 4 little egrets in 1974 in one heronry, and 1 of 4 night herons in another heronry in 1976 (1).

Mean gametocytaemia in infected night herons was 4 parasites per 1000 erythrocytes (range 2-30), and in little egrets it was 1 . Sex ratio of the gametocytes in night herons was in favour of macrogametocytes with a maximum of $1: 4$, in three little egrets it was $1: 1,1: 3$, and 1:5.

Although we did not sample every heronry each year, we believe that the distribution of the parasites is uneven in space and time. For instance in the heronry with chicks heavily infected in 1974 we found no parasites in 1976; in other heronries around the infected ones we found no evidence of infection in the same year. Of the two heronries with infected birds one was in a wood of medium size willows and the other was in a poplar plantation. Both locations were beside ponds and irrigation canals (described as heronry no. 1 and 3 by Fasola and Barbieri 1975).

(1) In 1979, further blood smears were collected from 77 night herons and 5 little egrets in 4 heronries. Of these, 9 night herons ( 2 out of 27 examined in one heronry and 7 out of 40 in another one) were infected by Leucocytozoon. This material was not used in the following description. 
Our observations are too limited to allow conclusions about the incidence of Leucocytozoonosis in wild populations. However, in the heronry where we found 11 infected chicks out of 15 in 1974 , the reproductive success was 2.2 young night herons fledged per nest (Fasola and Barbieri 1975). This value is only a little below normality for this species (pers. obs. and Hafner 1978), indicating that a significant mortality due to this parasite did not occur. In the literature, high patogenicity is sometimes attributed to species of Leucocytozoon in poultry and in wild birds, but cases of parasitized birds which are apparently healthy are also reported (Fallis et al. 1974).

In canals near the heronries with infected birds, we observed larvae and pupae of Eusimulium angustitarse (Lundstrom 1911) and E. latigonium (Rubrov 1956), Diptera Simulidae. The latter species, which is widespread in Italy, is thought by Rivosecchi (1978) a probable vector of Leucocytozoonosis in this zone. Larvae and pupae of the same species of Simulidae also were present near non-infected heronries.

\section{Description of the parasite.}

Host : Nycticorax nycticorax and Egretta garzetta.

LocAlity : Pavia, northern Italy.

Immature gametocytes (fig. 1, 2). Youngest parasites round with pale pink nucleus and deep red nucleolus. Mean diameter $4.8 \mu$ in night heron, no immature gametocytes found in egrets. Host cell nucleus very little distorted and placed peripherally.

Macrogametocytes (fig. 3, 4 and table II). Round, cytoplasm with a few vacuoles and many granulations (pseudopigmentation) stained deep blue; nucleus elongated, about 4 by $2.4 \mu$ in both hosts, placed eccentrically and stained pale pink; nucleolus, about $1.2 \mu$ in both hosts, stained deep red. Host cell nucleus elongated, stained brown red with clearer belt extending up to $1 / 3$ of parasite circumference. A significant proportion of the host cell cytoplasm remains attached to the parasite.

Microgametocytes (fig. 4, 5 and table II). Smaller than macrogametocytes and irregular in shape, cytoplasm stained slightly blue with pale pink chromatic granulations; diffused nucleus, and nucleolus sometimes evident.

Schizogony: unknown.

VECTOR: unknown.

Material: deposited in the International Reference Centre for Avian Haematozoa, Newfoundland, Canada, no. 67589.

In both hosts, the parasite is morphologically identical, except for dimensions that are significantly larger in the little egret (table $I I)$. 


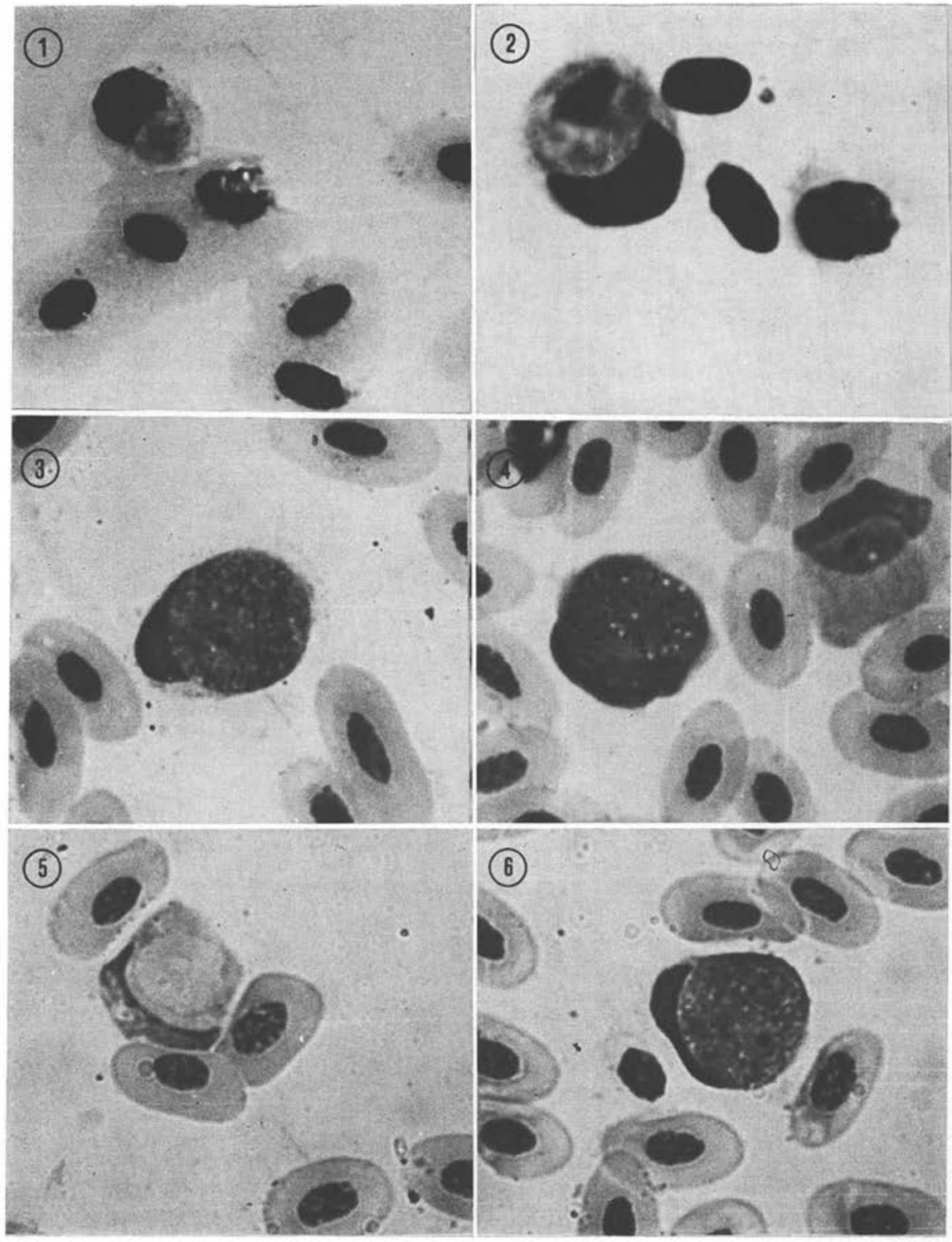

Fig. 1-5. Leucocytozoon sp. from Nycticorax nycticorax. 1, 2. Immature gametocytes. 3. Macrogametocyte. 4. Macrogametocyte (left) and microgametocyte (right) with evident nucleolus. 5. Microgametocyte without evident nucleolus.

Fig. 6. Leucocytozoon sp. from Egretta garzetta. Macrogametocyte. 


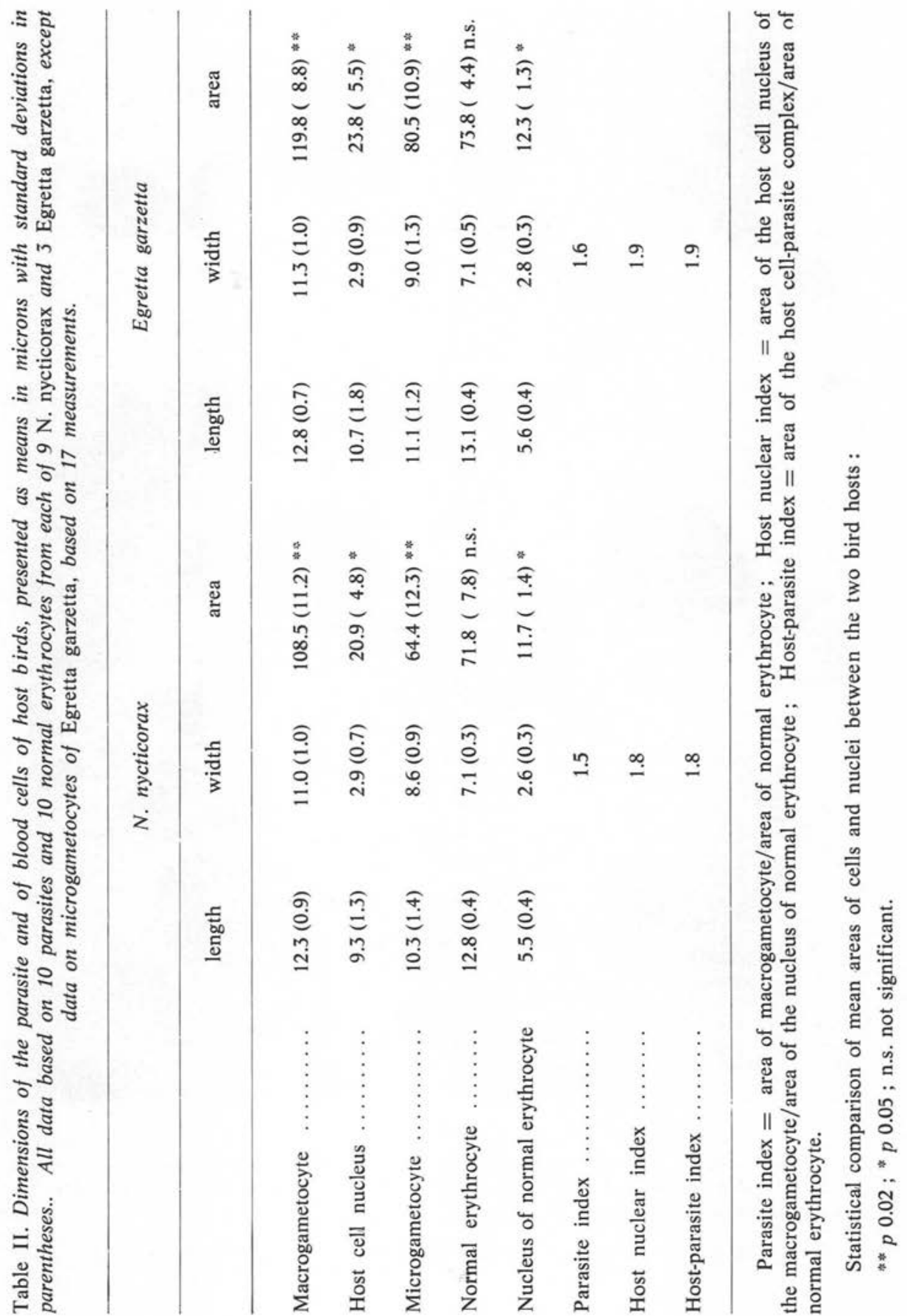


We calculated for our material the indexes (table II) proposed by Bennett et al. (1974) finding a small difference between the parasites in night herons and little egrets. This difference is due to the fact that gametocytes area larger in the egret, suggesting that these indexes should be considered together with the other morphological criteria.

\section{Comments}

Most species of Leucocytozoon are known and named only by gametocytes in peripheral blood of birds, without data on life cycle. Taxonomic criteria include morphology, shape and size of gametocytes of the parasite and distortion of the host cell. However the uncertain evaluation of these characters has resulted in many records of unidentified species and in cases of probable synonymy (Fallis et al. 1974). More difficulties arise because a species of Leucocytozoon may show variation in dimensions within the same or between different host species (Bennett and Campbell 1975, and table $I I)$ and because the host family specificity of the parasite is now in doubt after Bennett and Cameron (1975) found a single species parasitizing different families of Passeriformes.

These difficulties apply also to the comparison of our material with the description of Leucocytozoon recorder from Ardeidae (table I). Moreover some of these descriptions were made from small samples of parasites, they do not include illustrations, and the dimensions given cannot be compared by statistical analysis.

Bearing in mind these difficulties, we believe that our material:

- differs markedly from the description of $L$. ardeae (Rodhain et al. 1913), which has larger gametocytes which are equal in size, a host cell nucleus that may encircle the parasite and a recognisable star shaped nucleus in microgametocytes;

- differs slightly from the description of L. leboeufi (Mathis and Leger 1911), which has the nucleus of the microgametocyte round and both gametocytes equal in size and rather regular in shape;

- differs slightly from descriptions of $L$. sp. in night herons (Aubert and Heckenroth 1911) (nucleus of the macrogametocyte without nucleolus) and in N. nycticorax hoactli (Coatney 1938) (nucleus of the macrogametocyte round, and both gametocytes larger);

- is identical to the description of $L$. sp. (Franchini 1924) in night herons and in purple herons in northern Italy (except for the lack of granulations in macrogametocytes, and identical to the description of $L$. sp. in Butorides striatus atricapillus by Leger and Leger (1914).

The description of $L$. sp. in Butorides striatus (Rodhain et al. 1913) is insufficient for comparison. 
In summary, while only life cycle studies will answer taxonomic problems about Leucocytozoon spp., we provisionally suggest that the parasite observed by us:

- is distinct from $L$. ardeae and the synonyms of this species as proposed by Fallis et al. (1974) (records no. 1, 2, 3, 4 in table I);

- is probably distinct from L. leboeufi (no. 5 in table I) and from L. sp. of records no. 6,7 ;

- is conspecific with $L$. sp. of records no. 8, 9, 10 .

Acknowledgements. - We wish to thank G.F. Bennett for his suggestions, L. Rivosecchi for identifying Simulidae, and G. Bogliani and A. Meriggi for help in the field.

\section{References}

Aubert P., Heckenroth F.: Sur trois Leucocytozoon des oiseaux du Congo français. C.R. Soc. Biol., 1911, 70, 958-959.

Bennett G.F., Blancou J.: A note on the blood parasites of some birds from the Republic of Madagascar. J. Wildl. Dis., 1974, 10, 239-240.

Bennett G.F., Cameron M.F.: Mixed infection of species of Letcocytozoon in individual birds from Atlantic. Canada. J. Parasitol., 1975, 61, 1091-1095.

Bennett G. F., Campbell A.G.: Avian Leucocytozoidae. 1. Morphometric variation in three species of Leucocytozoon and some taxonomic implication. Can. J. Zool., 1975, 53, 800-812.

Bennett G. F., Khan R. A., Campbell A. G. : Leucocytozoon gruzi sp. n. (Sporozoa : Leucocytozoidae) from a sandhill crane, Grus canadensis (L.). J. Parasitol., 1974, 60, 359-363.

Coatney G. R. : Some blood parasites from birds of the Lake Okaboji Region. Am. Midl. Nat., 1938, 20, 336-340.

Fallis A.M., Desser S.S., Khan R. A.: On species of Leucocytozoon. Adv. Parasitol., 1974, 12, $1-67$.

Fasola M., Barbieri F.: Aspetti della biologia riproduttiva degli Ardeidi gregari. Ricerche Biol. Selvaggina, 1975, 62, 1-59. Istituto Nazionale Biologia della Selvaggina, Bologna.

Franchini G.: Observations sur les hematozoaires des oiseaux d'Italie. Ann. Inst. Pasteur, Paris, 1924, 38, 470-515.

Hafner H.: Le succès de reproduction de quatre espèces d'Ardéides Egretta g. garzetta L., Ardeola r. ralloides Scop., Ardeola i. ibis L., Nycticorax n. nycticorax L. en Camargue. Terre Vie, 1978, 32, 279-289.

Léger A., Léger M.: Leucocytozoon d'oiseaux du Haut-Sénégal et Niger. Bull. Soc. Pathol. Exot., 1914, 7, 391-395.

Mathis C., Léger M. : Leucocytozoon d'un paon, d'un crabier et d'un bengali du Tonkin. C.R. Soc. Biol., 1911, 70, 211-212.

de Mello I. F. : On Haematozoa of Indian birds. C.R. 12 Cong. Internat. Zool., Lisbon, 1937, 2, 1391-1445.

Peters J. L.: Checklist of birds of the world. Museum of Comparative Zoology, 1931, Cambridge, Mass., 1, pp. 97-142.

Rivosecchi L.: Simulidae. Diptera Nematocera. In «Fauna d'Italia ». Calderini, édit. Bologna, 1978.

Rodhain J., Pons C., Vandenbranden F., Bequaert J.: Notes sur quelques hématozoaires du Congo belge. Arch. Protistenk., 1913, 29, 259-278. 